\title{
PENGARUH PROPORSI TEPUNG RUMPUT LAUT Kappaphycus alvarezii, Eucheuma spinosum, DAN TEPUNG TAPIOKA TERHADAP DAYA TERIMA PANELIS DAN NILAI HARDNESS NUGGET JAMUR ENOKI (Flammulina velutipes)
}

\author{
[Effect of Kappaphycus alvarezii, Eucheuma spinosum Seaweed Flour, and Tapioca Flour Proportion \\ on Hedonic Value and Hardness Value in Enoki Mushroom Nugget (Flammulina velutipes)]
}

\author{
Choiroel Anam*, Theresia Nadia Andarini, Tiana Ayu Prima, dan \\ Bambang Sigit Amanto \\ Program Studi IImu Teknologi Pangan, Fakultas Pertanian, Universitas Sebelas Maret Surakarta \\ *Email : choiroelanam@staff.uns.ac.id
}

Diterima 3 Desember 2019 / Disetujui 7 Juli 2020

\begin{abstract}
Nugget is a restructured processed meat made from chicken generally. But chicken nuggets on the market generally contain high fat and low fiber so it is not recommended to be consumed continuously and in the long term. Therefore, a healthier diversification of fast food is needed, one of which is by using enoki mushrooms and seaweed. The use of these two materials is expected to be able to improve the physical characteristics and acceptability of healthier diversification of nuggets. This research used completely randomized design with 4 comparisons of seaweed flour and tapioca flour, which are $0 \mathrm{~g}: 50 \mathrm{~g} ; 5 \mathrm{~g}: 45 \mathrm{~g} ; 10$ $\mathrm{g}: 40 \mathrm{~g}$; and $15 \mathrm{~g}: 35 \mathrm{~g}$. Those parameters observed included physical (hardness) and sensory (color, aroma, taste, texture, and overall). Data was processed using SPSS statistical program with confidence level of $95 \%$, if the results were significantly different then the test continued with Duncan's Multiple Range Test (DMRT). Results indicate Kappaphycus alvarezii and Eucheuma spinosum seaweed flour significantly affected physic and sensory characteristics of enoki mushroom nuggets. The best formulation on the physical characteristics of enoki mushroom nuggets with the addition of Kappaphycus alvarezii and Eucheuma spinosum seaweed flour was $15 \mathrm{~g}: 35 \mathrm{~g}$. The best sensory acceptability characteristics of enoki mushroom nuggets with the addition of Kappaphycus alvarezii seaweed flour is $10 \mathrm{~g}: 40 \mathrm{~g}$ while the enoki mushroom nuggets with the addition of Eucheuma spinosum seaweed flour is $15 \mathrm{~g}: 35 \mathrm{~g}$.
\end{abstract}

Keywords : nugget, enoki mushroom, seaweed flour

\begin{abstract}
ABSTRAK
Nugget merupakan olahan daging restrukturisasi yang umumnya terbuat dari daging ayam. Namun nugget daging ayam yang beredar di pasaran umumnya mengandung lemak yang tinggi dan serat yang rendah sehingga tidak disarankan dikonsumsi terus menerus dan dalam jangka panjang. Oleh sebab itu diperlukan diversifikasi pangan cepat saji yang lebih sehat, salah satunya dengan penggunaan jamur enoki yang kaya nutrisi serta rumput laut yang kaya serat pangan. Penggunaan kedua bahan ini diharapkan mampu meningkatkan karakteristik fisik serta daya terima terhadap diversifikasi nugget yang lebih sehat. Penelitian ini menggunakan Rancangan Acak Lengkap dengan perbandingan tepung rumput laut dan tepung tapioka sebanyak 4 perlakuan yaitu $0 \mathrm{~g}: 50 \mathrm{~g} ; 5 \mathrm{~g}: 45 \mathrm{~g} ; 10 \mathrm{~g}: 40 \mathrm{~g}$; dan $15 \mathrm{~g}: 35 \mathrm{~g}$. Parameter yang diamati meliputi fisik (hardness) dan sensoris (warna, aroma, rasa, tekstur, dan overal). Data pengamatan diolah menggunakan program statistik SPSS dengan taraf kepercayaan $95 \%$, apabila hasil pengamatan berbeda nyata maka uji dilanjutkan dengan Duncan's Multiple Range Test (DMRT). Hasil penelitian ini menunjukkan bahwa penggunaan tepung rumput laut Kappaphycus alvarezii dan Eucheuma spinosum berpengaruh nyata terhadap karakteristik sensoris nugget jamur enoki. Formulasi terbaik pada karakteristik fisik nugget jamur enoki dengan penambahan tepung rumput laut Kappaphycus alvarezii dan Eucheuma spinosum adalah $15 \mathrm{~g}: 35 \mathrm{~g}$. Daya terima terbaik pada karakteristik sensoris nugget jamur enoki dengan penambahan tepung rumput laut Kappaphycus a/varezii adalah $10 \mathrm{~g}: 40 \mathrm{~g}$ sedangkan pada nugget jamur enoki dengan penambahan tepung rumput laut Eucheuma spinosum adalah $15 \mathrm{~g}: 35 \mathrm{~g}$.
\end{abstract}

Kata kunci : nugget, jamur enoki, tepung rumput laut

\section{PENDAHULUAN}

Nugget adalah jenis olahan makanan yang biasanya terbuat dari daging restrukturisasi yaitu daging yang digiling dan dibumbui, kemudian dilapisi oleh perekat tepung, pelumuran tepung roti (breading), 
dan digoreng setengah matang lalu dibekukan untuk mempertahankan mutunya selama penyimpanan (Astawan, 2007). Kandungan gizi nugget terdiri dari protein, lemak, karbohidrat, dan mineral (Wulandari dkk., 2016). Meski memiliki kandungan gizi yang cukup lengkap dan baik, namun umumnya nugget yang terbuat dari daging dengan kandungan lemak yang tinggi sebesar $15 \mathrm{~g}$ dan serat yang rendah sebesar $1 \mathrm{~g}$ (Agustine, 2010). Oleh sebab itu perlu adanya variasi bahan dasar dan bahan penunjang pembuatan nugget dengan kandungan nutrisi yang cukup dan juga memberi nilai fungsional bagi konsumen nugget. Bahan dasar yang bisa digunakan salah satunya adalah jamur. Jamur yang umum dipilih adalah jamur yang berwarna putih. Hal ini dimaksudkan agar hasil akhir nugget yang dihasilkan menyerupai nugget ayam pada umumnya. Jamur putih yang sedang banyak digunakan saat ini adalah jamur enoki. Sedangkan bahan penunjang yang berguna untuk meningkatkan kandungan serat pangan serta mampu memperbaiki tekstur nugget jamur adalah tepung rumput laut.

Jamur enoki (Flammulina velutipes) adalah jamur pangan yang berbentuk panjang-panjang dan berwarna putih seperti tauge. Jamur ini memiliki nama lain jamur tauge, jamur musim dingin, dan jamur jarum emas. Di wilayah dunia beriklim sejuk jamur ini tumbuh di alam bebas pada suhu udara rendah, mulai musim gugur hingga awal musim semi (Aditya dan Desi, 2011). Jamur ini biasa tumbuh di pohon enoki (Celtis sinensis) yang telah lapuk. Namun sekarang jamur ini telah banyak dibudidayakan. Jamur enoki memiliki kandungan nutrisi yang tinggi dan memiliki komponen-komponen bioaktif yang bermanfaat bagi manusia. Setiap 100 gram jamur enoki mengandung protein $31,2 \%$, lemak, $5,8 \%$ serat 3,3\%, dan abu 7,6 \% (Sharma et al., 2009 dalam Marzuki dkk., 2016). Jamur enoki juga memiliki banyak sifat fungsional. Kandungan senyawa flammulin berfungsi sebagai zat antikanker. Jamur enoki dilaporkan berfungsi sebagai anti oksidan alami (Jang et al., 2009), anti kanker dan jantung koroner (Martin, 2010), meningkatkan trombosit (Desinova, 2010), antibakteri (De Melo et al., 2009). Selain itu jamur ini juga menghasilkan nitrit oksida yang berfungsi sebagai zat antiinflamatori (Tang et al., 2016).

Rumput laut Kappaphycus alvarezii dan Eucheuma spinosum merupakan salah satu jenis rumput laut yang banyak dibudidayakan di Indonesia. Rumput laut jenis tersebut banyak diolah sebagai penghasil karagenan. Kappaphycus alvarezii menghasilkan karagenan jenis kappa sedangkan Eucheuma spinosum menghasilkan karagenan jenis iota. Kappaphycus alvarezii memiliki kandungan air sebesar $13,90 \%$; abu $17,09 \%$; protein 2,69\%; lemak 0,37\%; dan karbohidrat sebesar 65,00 \%(Santosa dan Deddy, 2016). Rumput laut Kappaphycus alvarezii mengandung karagenan sebesar $65,75 \%$ dari berat kering dan serat pangan total sebesar 25,05\% dari berat kering (Matanjum dan Suhaila, 2009). Eucheuma spinosum memiliki kandungan karbohidrat sebesar $53,44-56,80 \%$; protein 4,85 - 5,74\%; lemak 0,02 - 0,1\%; dan abu 18,70 - 19,55\% (Diharmi et al., 2011) serta serat pangan sebesar $45,30 \%$ (Dermid dkk., 2005). Eucheuma spinosum mengandung karagenan jenis iota karagenan yang cukup tinggi, yaitu berkisar antara $65-67 \%$ (Diharmi et al., 2011). Bahan pengikat pada pembuatan nugget berguna untuk meningkatkan cita rasa, meningkatkan daya ikat air, menurunkan penyusutan akibat pemasakan, dan memberi warna terang pada nugget (Heridiansyah dkk., 2014). Selain sebagai bahan pengikat yang mampu memperbaiki karakteristik fisik dan sensoris nugget, rumput laut yang digunakan juga kaya akan serat yang mampu menurunkan resiko berbagai penyakit, seperti penyakit kardiovaskular dan gangguan pencernaan. Oleh karena itu perlu dilakukan penelitian mengenai pembuatan nugget dengan bahan utama dan bahan pengikat yang lebih sehat serta memiliki daya terima yang baik.

\section{BAHAN DAN METODE}

\section{Bahan dan Alat}

Bahan-bahan yang diperlukan dalam penelitian ini adalah jamur enoki merk 
Versi Online:

http://Www.profood.unram.ac.id/index.php/profood e-ISSN: 2443-3446

GreenCo yang diperoleh dari supermarket di Surakarta, tepung rumput laut Kappaphycus alvarezii yang diperoleh dari toko online Dapur Rula Ketofood, tepung rumput laut Eucheuma spinosum yang diperoleh dari toko online Herbbeauty Yogyakarta, tepung tapioka, bawang putih, garam, lada bubuk, penyedap rasa, susu bubuk skim, telur, tepung panir, dan minyak goreng.

Alat-alat yang digunakan dalam penelitian ini meliputi alat pembuatan nugget dan alat pengujian fisik dan sensoris nugget, antara lain blender, alat deep-frying, kompor, loyang, panci pengukus, dan timbangan. Alat pengukur tekstur (hardness) nugget berupa seperangkat Universal Testing Machine (UTM).

\section{Metode}

Metode penelitian yang digunakan dalam penelitian adalah metode eksperimental sedangkan Rancangan penelitian yang digunakan adalah Rancangan Acak Lengkap (RAL) dengan satu faktor berupa perbandingan tepung rumput laut dan tepung tapioka yang terdiri dari 4 perlakuan, yatitu $0 \mathrm{gr}: 50 \mathrm{~g}$ (kontrol), $5 \mathrm{~g}: 45 \mathrm{~g} ; 10 \mathrm{~g}$ : $40 \mathrm{~g}$ dan $15 \mathrm{~g}: 35 \mathrm{~g}$. Hal ini diberlakukan untuk tepung rumput laut Kappaphycus alvarezii dan Eucheuma spinosum. Data hasil pengamatan dianalisis keragaman atau Analysis of Variance (ANOVA) pada taraf signifikansi 5\% menggunakan software SPSS. Apabila terdapat perbedaan nyata, maka dilakukan uji lanjut menggunakan Uji Duncan's Multiple Range Test (DMRT) pada taraf $5 \%$. Parameter yang diamati pada
Pro Food (Jurnal IImu dan Teknologi Pangan)

Vol 6 No. 1 Mei 2020

ISSN: 2443-1095

penelitian ini adalah parameter fisik berupa tekstur (hardness) (Nantapatavee et al., 2011) dan daya terima panelis secara hedonik dengan skala 1 (sangat tidak suka), skala 2 (tidak suka), skala 3 (biasa/netral), skala 4 (suka) dan skala 5 (sangat suka) (Soekarto, 1990).

Sebelum pembuatan nugget, perlu dipersiapkan peralatan dan bahan yang diperlukan. Jamur enoki dicuci bersih lalu ditiriskan, dipotong akarnya, dan dipotong menjadi tiga bagian. Selanjutnya jamur tersebut dimasukkan ke dalam blender, diberi satu butir telur, dan dihaluskan hingga terbentuk bubur jamur. Formulasi nugget jamur enoki dengan variasi rasio tepung tapioka dan tepung rumput laut Kappaphycus alvarezii maupun tepung rumput laut Eucheuma spinosum disajikan pada Tabel 1.

Bahan-bahan yang telah ditimbang sesuai formulasi dimasukkan ke dalam baskom yang dipisah pada baskom a untuk pembuatan nugget jamur enoki dengan proporsi penggunaan tepung rumput laut Kappaphycus alvarezii : tepung tapioka dan baskom b untuk pembuatan nugget jamur enoki dengan proporsi penggunaan tepung rumput laut Eucheuma spinosum : tepung tapioka, kemudian masing-masing bahan dalam baskom tersebut dicampur dengan proporsi tepung rumput laut : tepung tapioka (baskom a1 (0 gr : $50 \mathrm{~g}$ (kontrol)), baskom a2 $(5 \mathrm{~g}: 45 \mathrm{~g})$; baskom a3 $(10 \mathrm{~g}: 40 \mathrm{~g})$ dan baskom a4 (15 g : $35 \mathrm{~g})$ ) hingga homogen dan tidak ada tepung yang masih menggumpal, begitu pula hal yang sama dilakukan untuk perlakuan pada baskom $\mathrm{b}$.

Tabel 1. Formulasi Nugget Jamur Enoki dengan Variasi Rasio Tepung Tapioka dan Tepung Rumput Laut (RL)

\begin{tabular}{lccccc}
\hline \multicolumn{1}{c}{ Bahan (g) } & \multicolumn{3}{c}{ Jumlah } \\
\cline { 2 - 5 } & $\mathbf{0 : 5 0}$ & $\mathbf{5 : 4 5}$ & $\mathbf{1 0}: \mathbf{4 0}$ & $\mathbf{1 5 : 3 5}$ \\
\hline Jamur enoki & 100 & 100 & 100 & 100 \\
Tepung RL (Kappaphycus alvarezii) & $\mathbf{0}$ & $\mathbf{5}$ & $\mathbf{1 0}$ & $\mathbf{1 5}$ \\
Tepung RL (Eucheuma spinosum) & $\mathbf{5 0}$ & $\mathbf{4 5}$ & $\mathbf{4 0}$ & $\mathbf{3 5}$ \\
Tepung tapioka & 1 & 1 & 1 & 1 \\
Garam & 0,5 & 0,5 & 0,5 & 0,5 \\
Bubuk lada & 2 & 2 & 2 & 2 \\
Penyedap rasa & 4 & 4 & 4 & 4 \\
Bawang putih & 5 & 5 & 5 & 5 \\
Susu bubuk skim & 62,5 & 62,5 & 62,5 & 62,5 \\
Telur ayam & & &
\end{tabular}

Sumber : Yuliana dkk. (2013) dengan modifikasi 
Tahap berikutnya adonan nugget jamur enoki dituang ke dalam loyang yang telah disiapkan dan dimasukkan ke dalam panci pengukus selama 30 menit dengan suhu $80^{\circ} \mathrm{C}$. Adonan yang telah matang, selanjutnya didinginkan agar teksturnya mengeras. Selain itu pendinginan juga bertujuan untuk mempermudah pemotongan menjadi ukuran yang lebih kecil dengan ukuran $2 \times 2 \mathrm{~cm}$. Pemotongan dilakukan saat kondisi dingin agar nugget tidak rusak. Pelapisan dilakukan dua kali yaitu pertama dilakukan dengan putih telur, dengan adonan kukus yang telah dipotong digulirkan dalam putih telur secukupnya. Putih telur bersifat lengket sehingga dapat dimanfaatkan sebagai zat pelekat yang melekatkan adonan kukus dengan tepung panir. Sedangkan pelapisan kedua dilakukan dengan menggunakan tepung panir. Adonan kukus yang telah terlumuri dengan putih telur lalu dilumuri dengan tepung panir. Hal ini dilakukan agar dihasilkan nugget yang renyah. Selain itu juga untuk memperbaiki tekstur permukaan adonan kukus yang mungkin tidak rata. Proses berikutnya penggorengan yang diawali dari nugget siap goreng tersebut dikeluarkan dari freezer dan ditunggu hingga melunak. Penggorengan dilakukan dengan tujuan dihasilkan nugget berwarna keemasan yang menarik dan meningkatkan daya terima produk dengan dihasilkannya atribut sensori yang lebih baik. Setelah digoreng dan ditiriskan, nugget jamur tersebut dianalisis

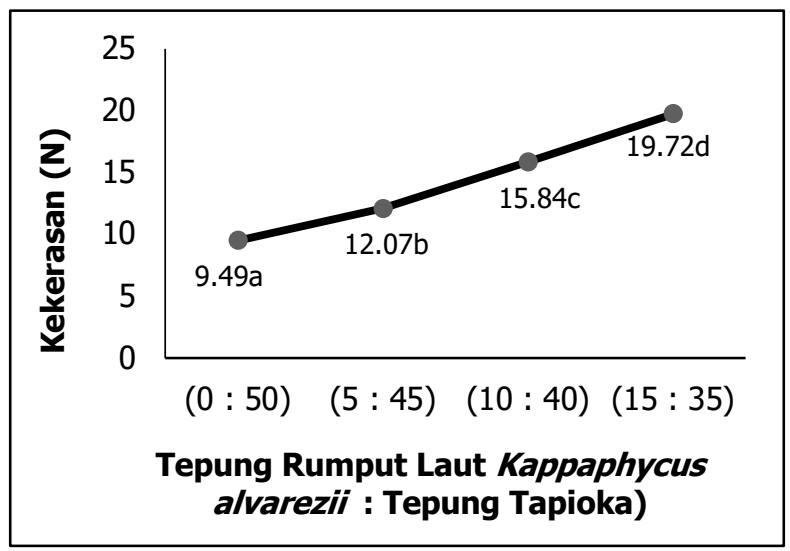

(a) secara fisik dan organoleptik sesuai dengan metode yang telah ditentukan.

\section{HASIL DAN PEMBAHASAN}

\section{Parameter Fisik}

Pengujian tekstur dilakkan dengan menggunakan seperangkat alat UTM (Universal Testing Machine) sehingga dapat menguji tekstur secara kuantitatif karena menunjukkan skala besarnya gaya yang dibutuhkan untuk perubahan bentuk. Uji kompresi pada pengujian UTM cocok untuk menentukan beberapa karakteristik mekanik, reologi dan ketegasan yang berbeda pada produk. Gaya kompresi ditentukan sebagai fungsi deformasi (perubahan bentuk). Pada umumnya pengujian tekstur menggunakan UTM berfungsi untuk mengetahui sifat mekanik dari bahan yang bersifat tipis dan lunak (Huerta dkk., 2010).

Gambar 1a menunjukkan jumlah gaya tekan pada sampel hingga mengalami perubahan bentuk ketika dikenakan gaya tekanan tersebut. Gaya tekan menunjukkan hubungan yang berbanding lurus terhadap tingkat kekerasan produk. Semakin besar gaya tekan yang diberikan, maka semakin keras tekstur produk tersebut. Hasil rata-rata kekerasan nugget pada penelitian ini berkisar antara 9,49 - 19,72 N. Pada Gambar tersebut menunjukkan grafik hubungan kekerasan nugget jamur enoki terhadap variasi rasio tepung tapioka dan tepung rumput laut Kappaphycus alvarezii.

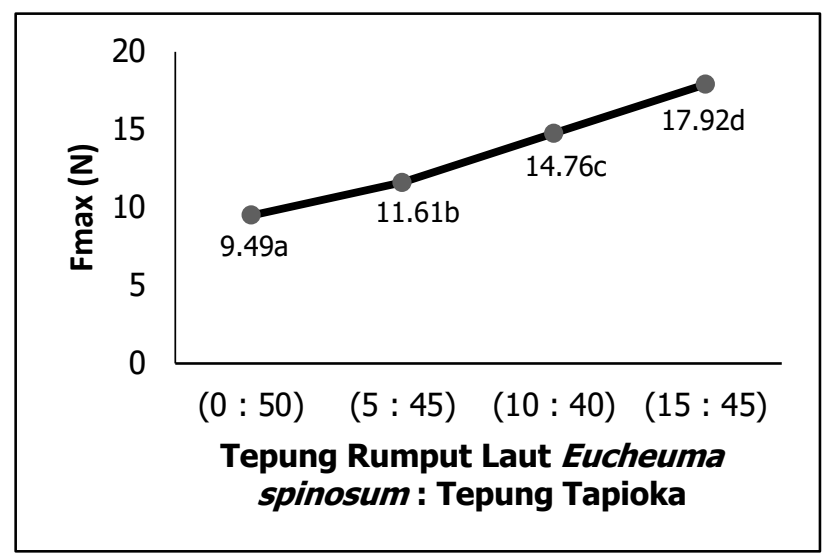

(b)

Gambar 1. (a) Hardness Nugget jamur Enoki dengan variasi rasio Tepung Rumput Laut Kappaphycus alvarezii dan Tepung Tapioka dan (b) Hardness Nugget jamur Enoki dengan variasi rasio Tepung Rumput Laut Eucheuma spinosum dan Tepung Tapioka 
Versi Online:

http://Www.profood.unram.ac.id/index.php/profood e-ISSN: 2443-3446

Terlihat bahwa adanya trend peningkatan kekerasan nugget seiring dengan bertambahnya tepung rumput laut Kappaphycus alvarezii.

Gambar 1b merupakan hasil pengukuran hardness nugget jamur enoki dengan variasi rasio tepung rumput laut Eucheuma spinosum dan tepung tapioka. Seperti halnya pada Gambar 1a penggunaan tepung rumput laut Kappaphycus alvarezii akan meningkatkan nilai hardness nugget. Hardness nugget jamur enoki dengan penambahan tepung rumput laut Eucheuma spinosum menunjukkan hasil 9,49-17,92 N. Hal ini disebabkan karena pada tepung rumput laut yang digunakan memiliki sifat dapat mengikat air pada adonan untuk meningkatkan kekenyalan produk nugget yang dihasilkan. Gel yang terbentuk ini begitu kuat dan elastis sehingga sehingga semakin sulit dipecah (Lukito dkk, 2017).

\section{Parameter Sensoris Warna}

Menurut Taub dan Singh (1998), warna merupakan salah satu parameter penting untuk menentukan persepsi terhadap kualitas bahan pangan karena penampakan visual dari bahan pangan akan menentukan apakah makanan tersebut layak dikonsumsi atau tidak. Hasil penilaian organoleptik tingkat kesukaan panelis terhadap parameter

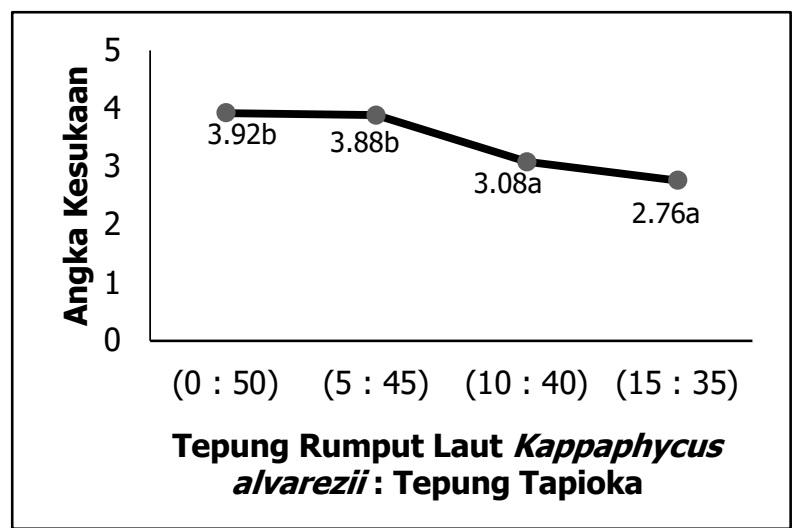

(a)
Pro Food (Jurnal Ilmu dan Teknologi Pangan)

Vol 6 No. 1 Mei 2020

ISSN: 2443-1095

warna nugget jamur enoki dengan variasi rasio tepung rumput laut Kappaphycus alvarezii dan tepung tapioka berdasarkan Gambar 2a, didapatkan nilai skor mengalami penurunan kesukaan dari skor 3 ke 2, dapat diartikan bahwa warna nugget memiliki penilaian kriteria biasa sampai kriteria tidak disukai oleh panelis.

Pada Gambar 2b didapatkan hasil analisa sensoris nugget jamur enoki dengan variasi rasio tepung rumput laut Eucheuma spinosum dan tepung tapioka berdasarkan uji kesukaan panelis terhadap mengalami penurunan nilai skor kesukaan dari skor 3 ke 2, dapat diartikan bahwa warna nugget memiliki penilaian kriteria biasa sampai kriteria tidak disukai oleh panelis. Berdasarkan Gambar 2a dan Gambar 2b dapat disimpulkan bahwa semakin banyak tepung rumput laut yang digunakan pada nugget akan menurunkan angka kesukaan panelis terhadap parameter warna. Hal ini disebabkan semakin banyak formulasi tepung rumput laut yang digunakan mengakibatkan terjadinya reaksi browning ketika proses pemanasan. Pencoklatan saat penggorengan juga disebabkan oleh adanya reaksi pencoklatan non enzimatis (reaksi Maillard) yaitu reaksi antara gula pereduksi dengan asam amino. Penggunaan tepung rumput laut juga berpengaruh terhadap warna produk.

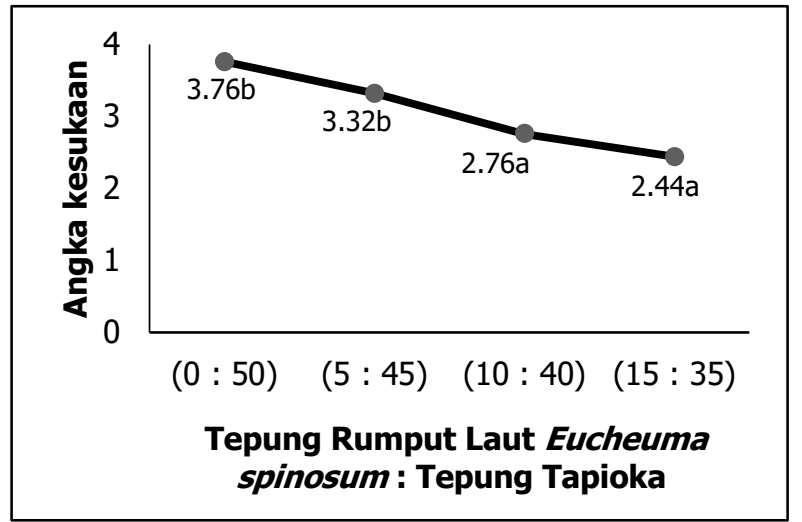

(b)

Keterangan:

*Skor: 1 = Sangat Tidak Suka; 2 = Tidak Suka; 3 = Biasa/Netral; 4: Suka; 5 = Sangat Suka

Gambar 2. (a) Daya Terima Panelis terhadap Warna Nugget Jamur Enoki dengan variasi rasio Tepung Rumput Laut Kappaphycus alvarezii dan Tepung Tapioka dan (b) rasio Tepung Rumput Laut Eucheuma spinosum dan Tepung Tapioka 
Versi Online:

http://Www.profood.unram.ac.id/index.php/profood e-ISSN: 2443-3446

Rumput laut yang digunakan pada penelitian ini mengandung karagenan dengan kandungan sulfat dan terdiri atas gugus galaktosa (Diharmi, 2016) yang akan bereaksi dengan asam amino lisin yang rentan terhadap kerusakan terutama pencoklatan non enzimatis. Asam amino lisin terkandung dalam jamur enoki yang digunakan yaitu sebesar 6,21 - 30,896 mg/g berat kering jamur (Tang et al., 2016). Selain berikatan dengan karagenan, asam amino yang terkandung dalam jamur juga bereaksi dengan gula pereduksi yang terdapat pada pati tapioka yang mengandung glukosa (Syamsuddin dkk., 2015).

\section{Aroma}

Aroma merupakan bau dari produk makanan, bau sendiri adalah suatu respon ketika senyawa volatil dari suatu makanan masuk ke rongga hidung dan dirasakan oleh sistem olfaktori. Senyawa volatil masuk ke dalam hidung ketika manusia bernafas atau menghirupnya, namun juga dapat masuk dari belakang tenggorokan selama seseorang makan (Kemp dkk., 2009).

Hasil penilaian organoleptik tingkat kesukaan panelis terhadap parameter aroma nugget jamur enoki dengan variasi rasio tepung rumput laut Kappaphycus alvarezii

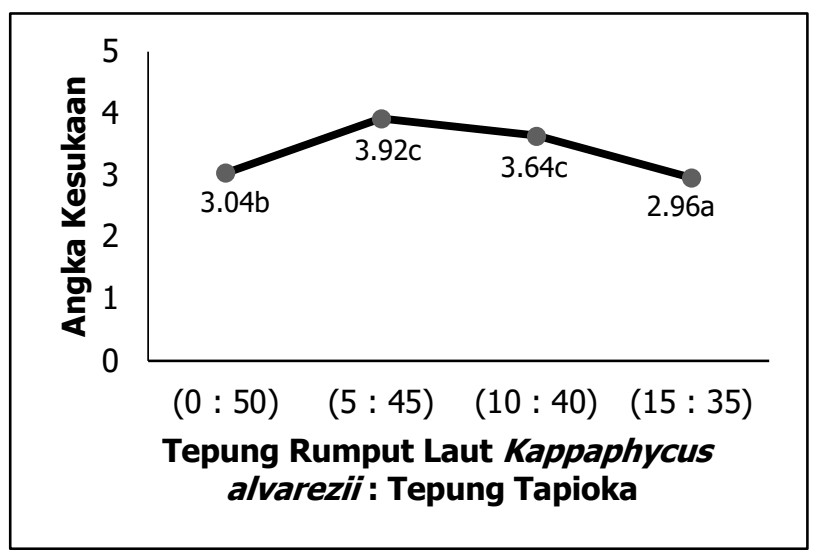

(a)
Pro Food (Jurnal Ilmu dan Teknologi Pangan)

Vol 6 No. 1 Mei 2020

ISSN: 2443-1095

dan tepung tapioka seperti disajikan dalam Gambar 3a, didapatkan skor kesukaan mengalami penurunan dengan nilai skor 3 ke skor 2, yang berarti bahwa aroma nugget memiliki kriteria penilaian biasa sampai tidak disukai oleh panelis. Hal ini disebabkan dominan pada aroma tepung rumput laut Kappaphycus alvarezii memiliki aroma amis. Didukung pendapat Santoso dkk. (2006), nilai aroma akan semakin menurun disebabkan rumput laut memiliki aroma laut (amis) yang cukup menyengat sehingga relatif kurang disukai.

Gambar 3b menunjukkan bahwa hasil uji kesukaan aroma nugget jamur enoki dengan variasi rasio tepung rumput laut Eucheuma spinosum dan tepung tapioka mengalami peningkatan dengan nilai skor 2 ke skor 3, yang berarti bahwa aroma nugget memiliki kriteri penilaian tidak disukai hingga biasa/netral oleh panelis. Hasil ini berbanding terbalik dengan penggunaan rumput laut Kappaphycus alvarezii yang dimana semakin tinggi penambahan rumput laut Kappaphycus alvarezii maka semakin menurun nilai kesukaan sedangkan pada penggunaan rumput laut Eucheuma spinosum semakin tinggi penambahan maka semakin meningkat nilai kesukaan oleh panelis terhadap nugget jamur enoki.

Keterangan:

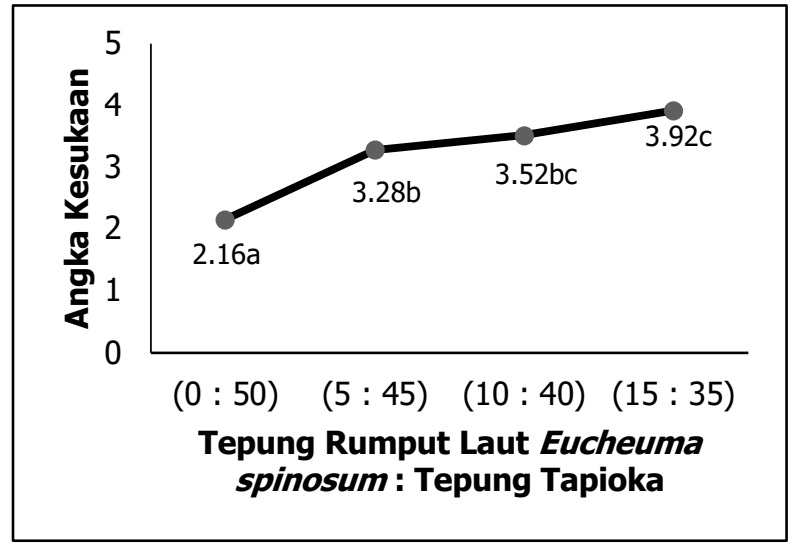

(b)

*Skor: 1 = Sangat Tidak Suka; 2 = Tidak Suka; 3 = Biasa/Netral; 4: Suka; 5 = Sangat Suka

Gambar 3. (a) Daya Terima Panelis terhadap Aroma Nugget Jamur Enoki dengan variasi rasio Tepung Rumput Laut Kappaphycus alvarezii dan Tepung Tapioka dan (b) variasi rasio Tepung Rumput Laut Eucheuma spinosum dan Tepung Tapioka 
Versi Online:

http://www.profood.unram.ac.id/index.php/profood e-ISSN: 2443-3446

Namun, bila melihat dari hasil nilai kesukaan pada kedua jenis rumput laut tersebut menghasilkan nilai kesukaan yang tidak jauh berbeda dengan rentang kriteria dari tidak suka hingga biasa/netral. Rumput laut memiliki aroma khas amis. Menurut Xiren dan Aminah (2014), aroma amis rumput disebabkan karena adanya kandungan amina atau amonia. Amonia merupakan senyawa yang terdiri dari unsur nitrogen dan hydrogen yang memiliki bau menyengat yang khas. Dapat disimpulkan bahwa hal ini diduga dari perbedaan jenis tepung rumput laut yang digunakan menyebabkan nilai kesukaan terhadap aroma nugget enoki dihasilkan berbanding terbalik. Namun, belum ada teori yang dapat mendukung perbedaan aroma dari jenis rumput laut.

\section{Rasa}

Salah satu faktor yang menentukan kualitas makanan adalah adanya senyawa citarasa. Senyawa citarasa merupakan senyawa yang menyebabkan timbulnya sensasi rasa (manis, pahit, masam, asin), trigeminal (astringent, dingin, panas) dan aroma setelah mengkonsumsi senyawa tersebut. Citarasa terutama dirasakan oleh reseptor aroma dalam hidung dan reseptor rasa dalam mulut (Midayanto dan Yuwono, 2014).

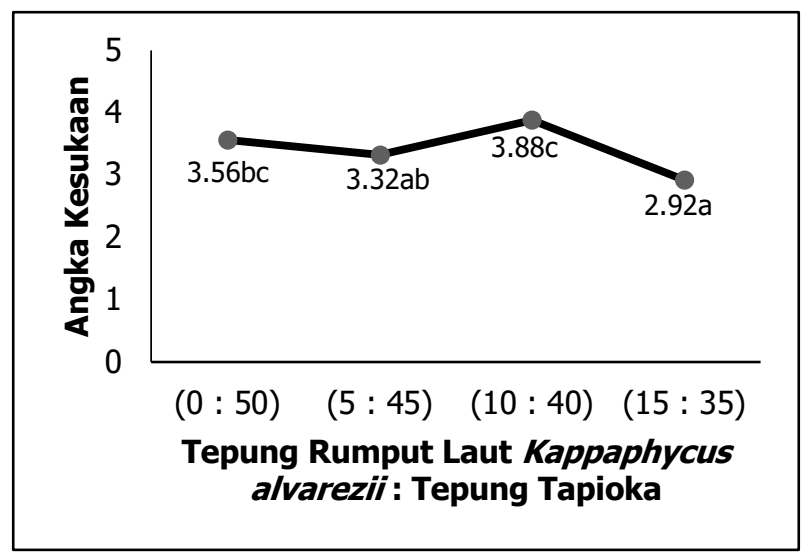

(a)
Pro Food (Jurnal Ilmu dan Teknologi Pangan)

Vol 6 No. 1 Mei 2020

ISSN: 2443-1095

Hasil uji organoleptik tingkat kesukaan panelis terhadap parameter rasa nugget jamur enoki dengan variasi rasio tepung rumput laut Eucheuma cottonii dan tepung tapioka berdasarkan Gambar 4a, didapatkan skor kesukaan mengalami penurunan nilai masih skor 3 ke skor 2, dapat diartikan bahwa rasa nugget memiliki penilaian kriteria biasa sampai tidak disukai oleh panelis. Rasa nugget dengan substitusi tepung rumput laut sampai konsentrasi $10 \%$ masih dapat diterima oleh panelis atau cenderung memiliki rasa netral atau stabil, tetapi apabila konsentrasi tepung rumput laut tinggi yaitu $15 \%$, rasa nugget menjadi tidak disukai panelis atau menimbulkan rasa khas yaitu sedikit pahit pada produk. Hal ini disebabkan kandungan asam amino pada rumput laut Kappaphycus alvarezii seperti lisin, fenilalanin, metionin, leusine dan valin memberikan rasa pahit (Sriket dkk., 2007).

Berbeda halnya dengan nugget jamur enoki dengan variasi rasio tepung rumput laut Eucheuma spinosum dan tepung tapioka yang menunjukkan hasil daya terima panelis yang semakin meningkat seiring pertambahan tepung rumput laut pada Gambar 4b. Hal ini diduga disebabkan sebagian besar rumput laut, mengandung asam aspartat dan asam glutamat yang cukup banyak dalam komposisi total asam amino.

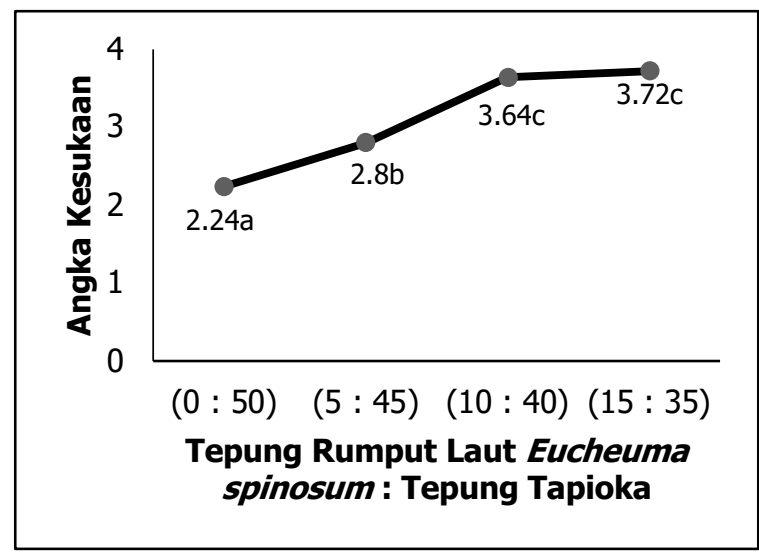

(b)

Keterangan:

*Skor: 1 = Sangat Tidak Suka; 2 = Tidak Suka; 3 = Biasa/Netral; 4: Suka; 5 = Sangat Suka

Gambar 4. (a) Daya Terima Panelis terhadap Rasa Nugget Jamur Enoki dengan variasi rasio Tepung Rumput Laut Kappaphycus alvarezii dan Tepung Tapioka dan (b) variasi rasio Tepung Rumput Laut Eucheuma spinosum dan Tepung Tapioka. 
Versi Online:

http://Www.profood.unram.ac.id/index.php/profood e-ISSN: 2443-3446

Kedua asam amino tersebut terdapat sekitar $22-44 \%$ dari total asam amino (Munda, 1977 dalam Fleurence, 1999). Selain kedua asam amino tersebut ditemukan pula kandungan asam amino threonin, lisin, triptofan, sistein, metionin dan histidin dalam jumlah kecil. Menurut Taufik dan Della (2015) kandungan asam amino glutamat, aspartat, dan threonin pada tepung rumput laut yang digunakan sebagai bahan pembuatan nugget jamur enoki berkontribusi terhadap timbulnya rasa gurih pada nugget yang dihasilkan. Oleh sebab itu panelis menilai biasa/netral terhadap rasa nugget dengan penggunaan tepung rumput laut sebesar $10-15 \%$.

\section{Tekstur}

Tekstur merupakan ciri suatu bahan sebagai akibat perpaduan dari beberapa sifat fisik yang meliputi ukuran, bentuk, jumlah dan unsur-unsur pembentukan bahan yang dapat dirasakan oleh indera peraba dan perasa, termasuk indera mulut dan penglihatan (Tarwendah, 2017). Hasil penilaian organoleptik tingkat kesukaan panelis terhadap parameter tekstur nugget jamur enoki dengan variasi rasio tepung rumput laut Kappaphycus alvarezii dan tepung tapioka berdasarkan Gambar 5a, didapatkan skor kesukaan mengalami

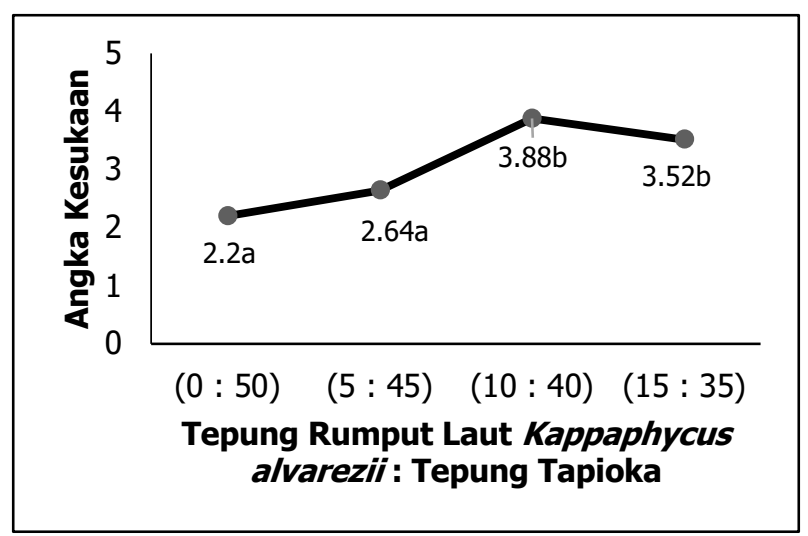

(a)
Pro Food (Jurnal Ilmu dan Teknologi Pangan)

Vol 6 No. 1 Mei 2020

ISSN: 2443-1095

peningkatan diantara 2 sampai 3, dapat diartikan bahwa tekstur nugget jamur enoki memiliki penilaian kriteria dari tidak disukai sampai biasa/netral oleh panelis. Pada Gambar $5 b$ didapati hasil penilaian organoleptik tingkat kesukaan panelis terhadap parameter tekstur nugget jamur enoki dengan variasi rasio tepung rumput laut Eucheuma spinosum dan tepung tapioka dengan skor kesukaan mengalami peningkatan diantara 2 sampai 3, dapat diartikan bahwa tekstur nugget jamur enoki memiliki penilaian kriteria dari tidak suka sampai biasa/netral oleh panelis. Dari kedua hasil tersebut dipengaruhi dari tekstur kekompakan penggunaan tepung rumput laut. Menurut Hudaya (2008), penambahan tepung rumput laut akan menghasilkan tekstur yang tidak kompak sebab tepung rumput laut memiliki partikel yang tidak kompak. Namun, dari tidak kompakannya tekstur pada tepung rumput laut, ternyata dengan penambahan rasio penambahan tepung tapioka juga dapat meminimalisir tekstur yang tidak kompak dikarenakan memiliki fungsi sebagai bahan penstabil dan pembentuk tekstur. Menurut Widyastuti (1999), bahwa tapioka dalam pembuatan makanan berfungsi sebagai pengental (penstabil) dan pembentuk tekstur.

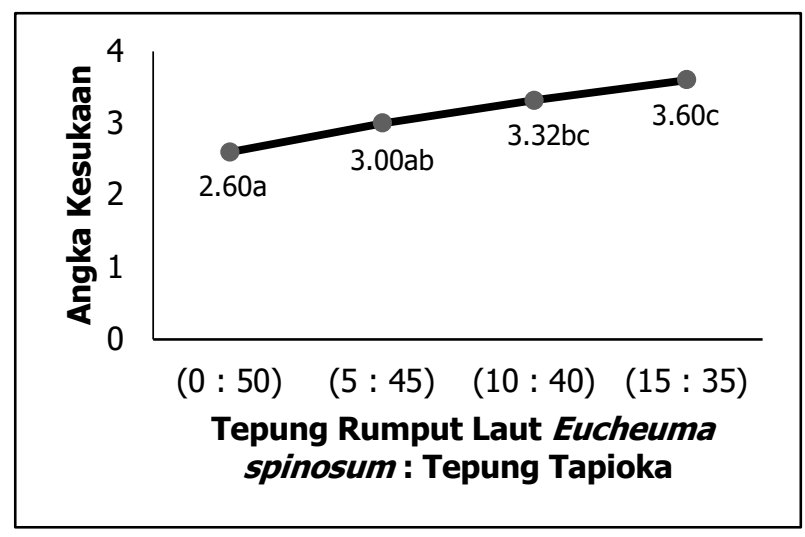

(b)

Keterangan:

*Skor: 1 = Sangat Tidak Suka; 2 = Tidak Suka; 3 = Biasa/Netral; 4: Suka; 5 = Sangat Suka

Gambar 5. (a) Daya Terima Panelis terhadap Tekstur Nugget Jamur Enoki dengan variasi rasio Tepung Rumput Laut Kappaphycus alvarezii dan Tepung Tapioka dan (b) variasi rasio Tepung Rumput Laut Eucheuma spinosum dan Tepung Tapioka 


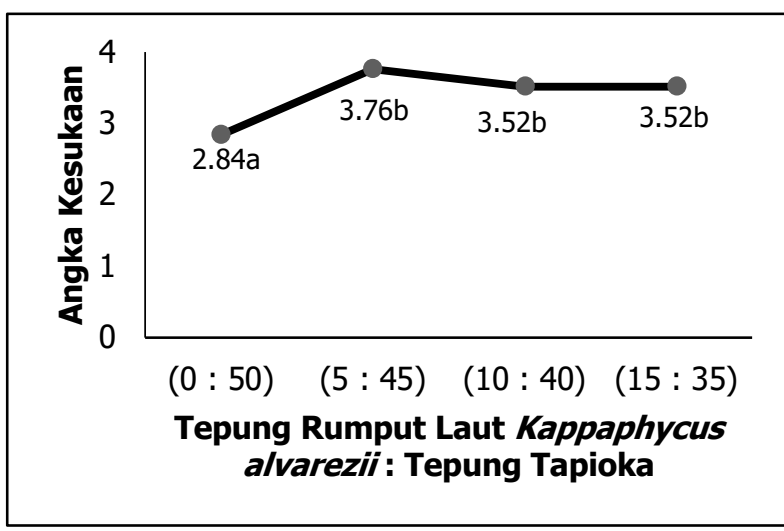

(a)

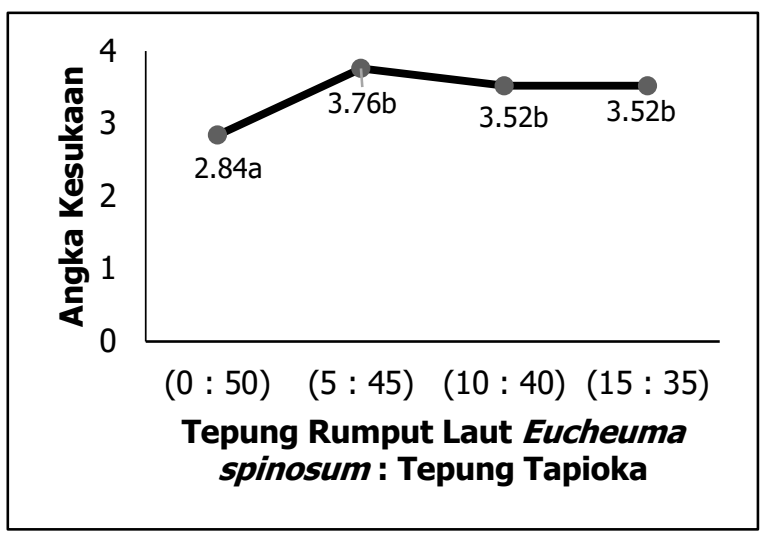

(b)

Keterangan:

*Skor: 1 = Sangat Tidak Suka; 2 = Tidak Suka; 3 = Biasa/Netral; 4: Suka; 5 = Sangat Suka

Gambar 6. (a) Daya Terima Panelis terhadap Keseluruhan Nugget Jamur Enoki dengan variasi rasio Tepung Rumput Laut Kappaphycus alvarezii dan Tepung Tapioka dan (b) variasi rasio Tepung Rumput Laut Eucheuma spinosum dan Tepung Tapioka

\section{Overall}

Parameter keseluruhan (overall) digunakan dalam uji hedonik untuk mengukur tingkat kesukaan panelis terhadap keseluruhan atribut mutu (warna, aroma, rasa dan tekstur) yang ada pada produk. Tingkat kesukaan dan daya terima panelis terhadap suatu produk bisa jadi tidak hanya dipengaruhi oleh satu faktor, namun dapat dipengaruhi oleh berbagai macam faktor sehingga menimbulkan penerimaan yang utuh. Hasil penilaian organoleptik tingkat kesukaan panelis terhadap parameter overall nugget jamur enoki dengan variasi rasio tepung rumput laut Kappaphycus alvarezii dan tepung tapioka berdasarkan Gambar 6a, didapatkan skor kesukaan mengalami peningkatan diantara skor 2 sampai 3, dapat diartikan bahwa overall nugget jamur enoki memiliki penilaian kriteria tidak suka sampai biasa/netral oleh panelis. Pada Gambar 6b daya terima panelis terhadap keseluruhan nugget jamur enoki dengan variasi rasio tepung rumput laut Eucheuma spinosum dan tepung tapioka menunjukkan skor kesukaan mengalami peningkatan diantara skor 2 sampai 3, dapat diartikan bahwa overall nugget jamur enoki memiliki penilaian kriteria tidak suka sampai biasa/netral oleh panelis. Dari hasil tersebut dapat disimpulkan bahwa keseluruhan atribut mutu organoleptik yaitu warna, aroma, rasa dan tekstur dipengaruhi oleh karakteristik yang dimiliki tepung rumput laut dan tepung tapioka terhadap nilai kesukaan nugget jamur enoki. Karakteristik pada tepung rumput laut yang digunakan yaitu berwarna putih sedikit kecokelatan, beraroma sedikit amis, berasa pahit dan tekstur kurang halus. Sedangkan karakteristik tepung tapioka yang digunakan yaitu berwarna putih, tidak beraroma, berasa pahit dan tekstur halus.

\section{KESIMPULAN}

Berdasarkan hasil analisis dan pembahasan yang terbatas pada ruang lingkup penelitian ini, maka dapat ditarik beberapa kesimpulan bahwa parameter fisik yaitu hardness nugget jamur enoki dengan variasi rasio tepung rumput laut Kappaphycus alvarezii dan tepung tapioka maupun nugget jamur enoki dengan variasi rasio tepung rumput laut Eucheuma spinosum dan tepung tapioka, semakin banyak tepung rumput laut yang digunakan maka akan semakin tinggi nilai hardness nugget jamur enoki. Sensori nugget jamur enoki dengan variasi rasio tepung rumput laut Kappaphycus alvarezii dan tepung tapioka menunjukkan hasil bahwa daya terima panelis tertinggi terletak pada formulasi 10 : 40, sedangkan pada nugget jamur enoki dengan variasi rasio tepung rumput laut Eucheuma spinosum dan tepung tapioka pada formulasi $15: 35$. 
Versi Online:

http://Www.profood.unram.ac.id/index.php/profood e-ISSN: 2443-3446

\section{DAFTAR PUSTAKA}

Aditya, R. dan Desi S. 2011. 10 Jurus Sukses Beragribisnis Jamur. Penebar Swadaya. Jakarta.

Agustine, E. S. 2010. Evaluasi Karakteristik Fisikokimiawi dan Sensoris Chicken Nugget Dengan Substitusi Tepung Bekatul. Skripsi. Fakultas Teknologi Pertanian. Universitas Katolik Soegijapranata. Semarang.

Astawan, M. 2007. Nugget Ayam Bukan Makanan Sampah. PT. Gramedia Pusaka Utama. Jakarta.

De Melo, M. R., Paccola-Meirelles, Luzia D., De Jesus F., Terezinha, Kazue I. dan Noemia. 2009. Influence of Flammulina Velutipes Mycelia Culture Conditions On Antimicrobial Metabolite Production. Mycoscience $50: 78-81$.

Dermid, Mc. Karla J., Brooke Stuerckea dan Owen J. Haleakala. 2005. Total Dietary Fiber Content in Hawaiian Marine Algae. Botanica Marina 48.

Desinova N. P. 2010. History of The Study Thrombolytic and Fibrinolytic Enzymes of Higher Basidiomycetes Mushrooms. International Journal of Medicinal Mushrooms 12 (3) : 317-326.

Diharmi, A. 2016. Karakteristik Fisika-Kimia Karagenan Rumput Laut Merah Eucheuma spinosum dari Perairan Nusa Penida, Sumenep dan Takalar. Thesis. Institut Pertanian Bogor. Bogor.

Diharmi, A., Dedi F., Nuri A. dan Endang S. H. 2011. Karakteristik Komposisi Kimia Rumput Laut Merah (Rhodophycea) Eucheuma spinosum yang Dibudidayakan dari Perairan Nusa Penida, Takalar, dan Sumenep. Berkala Perikanan Terubuk 39 (2) : 61-66.

Fleurence, J. 1999. Seaweed Protein: Biochemistry, Nutritional Aspects and Potential Uses. Review of Trends in Food Chemistry $10: 25-28$.

Heridiansyah, N., Hesti N. dan Darius. 2014. Pengaruh Jenis Tempe dan Bahan Pengikat Terhadap Karakteristik
Pro Food (Jurnal Ilmu dan Teknologi Pangan)

Vol 6 No. 1 Mei 2020

ISSN: 2443-1095

Nugget Tempe. AGRITEPA 1 (1) : 109-118.

Huerta, E., J.E. Corona dan A.I. Oliva. 2010. Universal Testing Machine For Mechanical Properties of Thin Materials. Journal Revista Mexicana De Fi 'Sica 56 (4) : 317-322.

Jang, M-S., Hee-Yeon P., Hideki U. dan Toshiaki O. 2009. Antioxidative Effects of Mushroom Flammulina velutipes Extract On Polyunsaturated Oils In Oil-in-Water Emulsion. Food Sci. Biotechnol 18 (3) : 604- 609.

Kemp, S. E., Tracey H. dan Joanne H. 2009. Sensory Evaluation: A Practical Handbook. Wiley Blackwell, United Kingdom.

Lukito, M. S., Giyarto dan Jayus. 2017. Sifat Fisik, Kimia, dan Organoleptik Dodol Hasil Variasi Rasio Tomat dan Tepung Rumput Laut. Jurnal Agroteknologi 11 (1) : 82 - 95 .

Martin, P.2010. Medicinal Mushrooms $A$ clinical Guide. Mycology Press. UK.

Marzuki, B. M., Tatang S. E. dan Joko K. 2016. Pengaruh Penambahan Berbagai Takaran Ampas Tahu pada Media Bibit Induk Jagung Terhadap Pertumbuhan Miselium dan Bobot Bibit Induk Jamur Enoki (Flammulina Velutipes (Curt.:Fr.) Singer.). Jurnal Pangan 147-152.

Matanjum, N. dan Suhaila M. 2009. Nutrient Content of Tropical Edible Seaweeds, Eucheuma cottonii, Caulerpa lentillifera and Sargassum polycystum. Journal Appl Phyco 21 : $75-80$.

Midayanto, D. N. dan Yuwono S. S. 2014. Penentuan Atribut Mutu Tekstur Tahu untuk Direkomendasikan Sebagai Syarat Tambahan Dalam Standar Nasional Indonesia. Jurnal Pangan dan Agroindustri 2 (4) : 259-267.

Nantapatavee, P., A. Jangchud, K. Jangchud, J. Lin dan T. Harnsilawati. 2011. Effect of Physical Properties on Consumer Preference of Nugget. Thai Journal of Agriculture Science 44 (5) : 519-525.

Santosa, A. dan Deddy K. 2016. Karakteristik Tepung Rumput Laut (Eucheuma 
Versi Online:

http://WwW.profood.unram.ac.id/index.php/profood e-ISSN: 2443-3446

cottonii). National Conference of Applied Sciences, Engineering, Business and Information Technology $346-361$.

Santoso, J., O. A. Lestari. dan N. A., Anugrahati. 2006. Peningkatan Kandungan Serat Makanan dan Iodium Pada Mi Kering Melalui Subtitusi Tepung Terigu Dengan Tepung Rumput Laut. Jurnal IImu Teknologi Pangan 4 (2) : 131-145.

Soekarto, S.T. 1990. Dasar-Dasar Pengawasan dan Standarisasi Mutu Pangan. Jurusan Teknologi Pangan dan Gizi. Departemen Pendidikan dan Kebudayaan. Direktorat Jenderal Pendidikan Tinggi. Pusat Antar Universitas Pangan dan Gizi Institut Pertanian Bogor. Bogor.

Sriket P, Benjakul S., Visessanguan W. dan Kijroongrojana K. 2007. Comparativestudies On Chemical Composition and Thermal Properties of Black Tiger Shrimp (Penaeus monodon) and White Shrimp (Penaeus vannamel) Meats. Food Chemistry 103 (4) : 1199-1207.

Syamsuddin, N., Lahming dan Muhammad W. C. 2015. Analisis Kesukaan Terhadap Karakteristik Olahan Nugget yang Disubtitusi dengan Rumput Laut dan Tepung Sagu. Jurnal Pendidikan Teknologi Pertanian 1 : 1-11.

Tang, C., P. Ching-Xin Hoo, Loh Teng-Hern T., P. Pusparajah, Tahir M. K., Learn-Han L., Bey-Hing G. dan Kok-Gan C. 2016. Golden Needle Mushroom: A Culinary Medicine with Evidenced-Based Biological Activities and Health Promoting Properties. Frontiers in Pharmacology 7 (474).

Tarwendah, I. P. 2017. Review: Studi Komparasi Atribut Sensoris dan Kesadaran Merek Produk Pangan. Jurnal Pangan dan Agroindustri 5 (2) : 66-73.

Taub, I. A. and R. D. Singh. 1998. Food Storage Stability. CRS Press. New York.

Taufik, M. dan Della R. 2017. Fraksinasi dan Karakterisasi Komponen Rasa Gurih pada Bumbu Penyedap. Jurnal
Pro Food (Jurnal Ilmu dan Teknologi Pangan)

Vol 6 No. 1 Mei 2020

ISSN: 2443-1095

Aplikasi Teknologi Pangan 6 (1) : 36-38.

Widyastuti, E. S. 1999. Studi Tentang Penggunaan Tapioka, Pati Kentang dan Pati Modifikasi Dalam Pembuatan Bakso Daging Sapi. Thesis. Program Studi Ilmu Ternak. Program Pascasarjana Universitas Brawijaya. Malang.

Wulandari, Eka, Lilis Suryaningsih, Andry Pratama, Denna Surahman Putra, Nonong Runtini. 2016. Karakteristik Fisik, Kimia dan Nilai Kesukaan Nugget Ayam Dengan Penambahan Pasta Tomat. Jurnal IImu Ternak 16 (2) : 1-5.

Yuliana, N., Yoyok B. P. dan A.Hintono. 2013. Kadar Lemak, Kekenyalan dan Cita Rasa Nugget Ayam yang Disubsitusi Dengan Hati Ayam Broiler. Animal Agriculture Journal 2 (1) : 308. 